\title{
HR recruitment optimization strategy for large food factories with the use of lean manufacturing methods
}

\author{
Karina Barmuta ${ }^{1, *}$, and Olga Grishchenko ${ }^{2}$ \\ ${ }^{1}$ Don State Technical University, 1, Gagarinsquare, 344000, Rostov-on-Don, Russia \\ ${ }^{2}$ Taganrog Institute named after A.P. Chekhov (Branch) of RSUE, 48, Initiative str., 347936, \\ Taganrog, Russia
}

\begin{abstract}
The issues related to the study of Human Resource processes optimization strategy with the use of the Lean Manufacturing system are highlighted in the paper. The HR specialist role in the recruitment system is reviewed. It is necessary to improve the current process, affecting each of its stages, to increase the efficiency of personnel selection and expand the influence on final result achievement in the food industry enterprises. The concept of HR as a business partnership (HRBP) is developed, which makes it possible to independently flag the need for personnel in accordance with company's business plan and in some cases also to force changes needed to increase the effect of recruitment process for the company. Modified personnel selection system is introduced and the algorithm for its implementation based on Lean principles with the specified optimization effect in reducing personnel turnover rate and losses is developed. The value map, competency matrix and the list of actions needed to optimize recruitment are worked out.
\end{abstract}

\section{Introduction}

The formal viewing of the job seeker, outdated headhunting methods, excessively long stages of recruitment - all these problems require not only optimization measures and search for solution techniques, but also a review of the HR specialist role in the recruitment system.

Current trends of the world market operating environment demand from the HR department to be aware of the global company's development strategy, the ability to consider their contribution to the business.

Pointing at the inevitability and necessity of constant transformation, the foreign researchers suggested a composite model of human resource management, which includes such roles of the HR department as "strategic partner", "staff leader", "change agent" and "expert in the field of administration" [1-2].

This composite model has become the basis of the HR business partnership concept ("HRBP" - Human Resource Business Partner") that is popular and widely applied in the world. The concept describes a new model of interaction between HR functions and the

*Correspondingauthor:carinaba@yandex.ru 
business [3-4]. The purpose and functions of HR as a business partner include: HR policy design and implementation supervision; working with management on planning and implementing programs to support the company in the long-term and short-term outlook; employee cycle management; internal communications; local projects management [5-6]. The modified model of the system can be presented as follows (Figure 1).

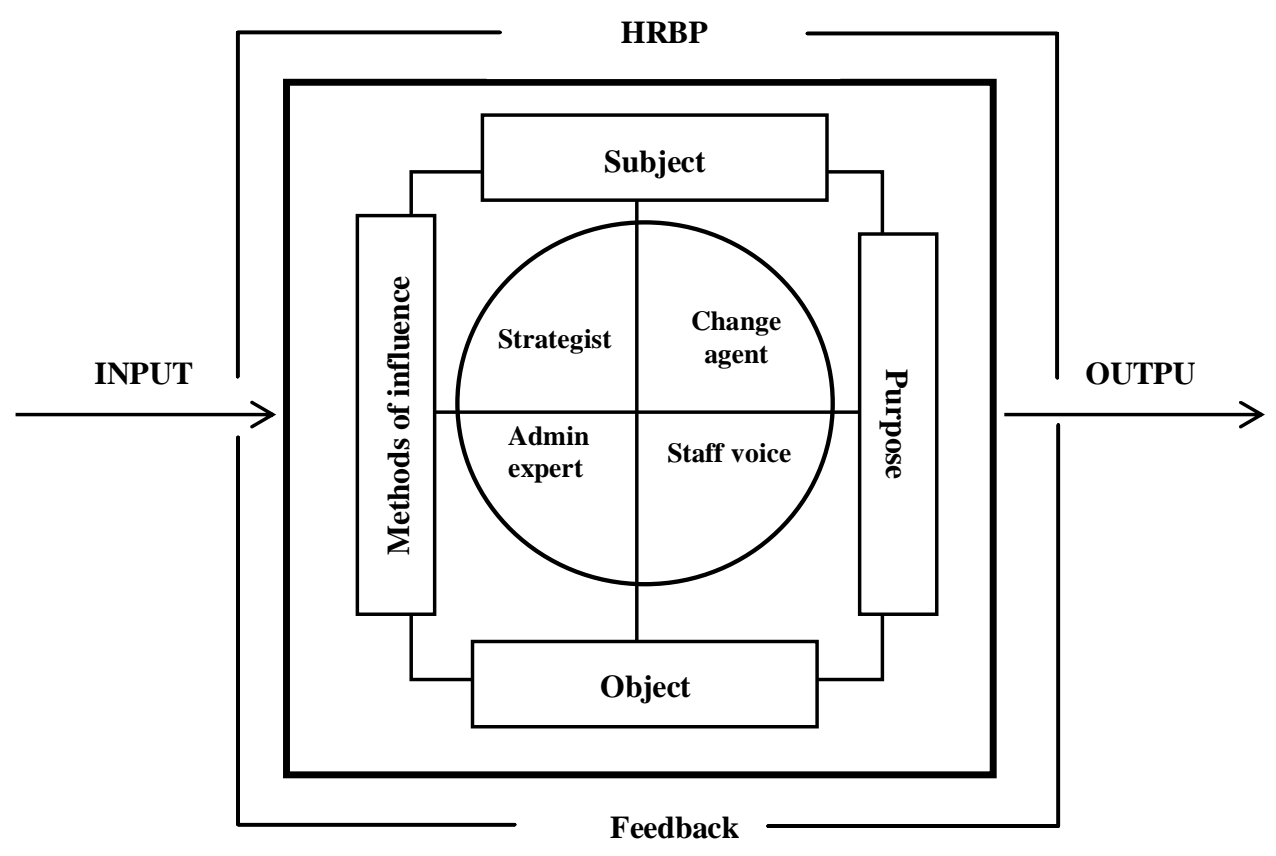

Fig. 1. The modified model of the recruitment system.

The purpose of the modified system is to choose an employee who not only meets the requirements of the job vacancy with professional and personal qualities, but also has the motivation and line for development corresponding to the company's values. It is important for the headhunter to consider the job seeker potential, his intentions and motives, to study his personality system and assess his potential value for the company.

\section{Materials and methods}

Currently, food industry enterprises have the opportunity to increase the efficiency of recruitment by using new ideas and expand the influence on the achievement of the final outcome, but it is necessary to optimize the current process, affecting every stage of it.

To implement the modified recruitment system we suggest applying the developed methodology based on Lean principles [7-12]. The optimization effect consists in decrease 
of personnel turnover rate and, as a result, in reduction of losses from the influence of the factor. The methodology for optimizing recruitment process is presented in Figure 2.

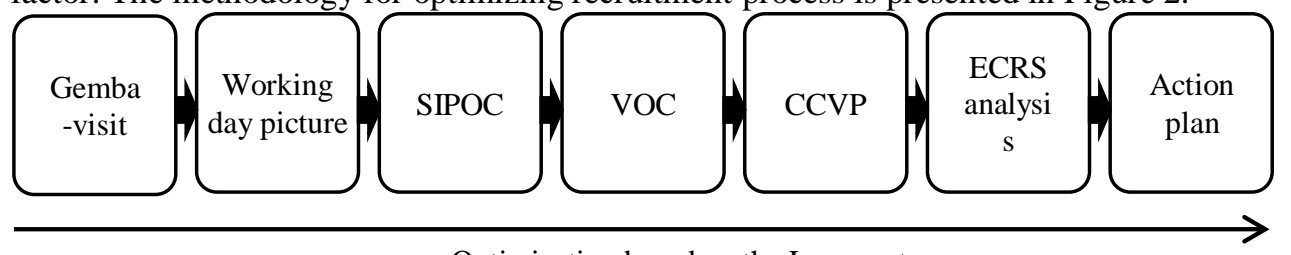

Optimization based on the Lean system

Fig. 2. Methodology of recruitment process optimization based on the Lean system, Source: [6-7].

On the ground of the data acquired in the previous steps the action plan is made up intended for use to solve existing problems or narrow down their impact, as well as to increase the recruitment efficiency as a whole. Within the scope of measures development, the corresponding KPI are suggested to use for data comparison prior to optimization and after it in order to determine the efficiency of actions. The actions with selected key performance indicators are demonstrated in table 1.

Table 1. The list of actions for recruitment optimizing, Source: [8-10].

\begin{tabular}{|c|c|c|c|c|}
\hline \multirow[b]{2}{*}{ № } & \multirow[b]{2}{*}{ Action } & \multicolumn{3}{|c|}{ KPI } \\
\hline & & Indicator & $\begin{array}{c}\text { Prior to } \\
\text { implementa } \\
\text { tion } \\
(2019)\end{array}$ & $\begin{array}{l}\text { After } \\
\text { implement } \\
\text { ation } \\
(\mathbf{2 0 2 0})\end{array}$ \\
\hline 1 & 2 & 3 & 4 & 5 \\
\hline \multirow{2}{*}{1} & \multirow{2}{*}{$\begin{array}{l}\text { Participation in } \\
\text { managerial rallies to } \\
\text { inform the executive staff } \\
\text { of the company about the } \\
\text { situation on the labour } \\
\text { market and to increase its } \\
\text { embeddedness }\end{array}$} & $\begin{array}{l}\text { Applicant } \\
\text { assessment by the customer } \\
\text { according to a 5-points system }\end{array}$ & 4.2 & 4.5 \\
\hline & & $\begin{array}{l}\text { Recruitment quality assessment } \\
\text { by the customer according to a } \\
\text { 5-points system }\end{array}$ & 4.5 & 4.8 \\
\hline \multirow{3}{*}{2} & \multirow{3}{*}{$\begin{array}{l}\text { Competency matrix } \\
\text { development }\end{array}$} & $\begin{array}{l}\text { The duration of the selection } \\
\text { process per } 1 \text { applicant before } \\
\text { approval for the position (days): } \\
\text {-worker } \\
\text { - professional employee }\end{array}$ & $\begin{array}{l}17 \\
48 \\
\end{array}$ & $\begin{array}{l}10 \\
33\end{array}$ \\
\hline & & $\begin{array}{l}\text { Reduction of complaints against } \\
\text { assessment subjectivity: } \\
\text { - applicants } \\
\text { - customers }\end{array}$ & $\begin{array}{l}4 \\
5\end{array}$ & $\begin{array}{l}2 \\
3\end{array}$ \\
\hline & & $\begin{array}{l}\text { Filling in the talent pool: } \\
\text { - key positions } \\
\text { - working positions }\end{array}$ & $\begin{array}{l}56 \% \\
76 \%\end{array}$ & $\begin{array}{l}74 \% \\
82 \%\end{array}$ \\
\hline
\end{tabular}




\begin{tabular}{|c|c|c|c|c|}
\hline 3 & $\begin{array}{l}\text { Expansion of the search } \\
\text { scope: } \\
\text { - interaction with } \\
\text { universities; } \\
\text { - social networks; } \\
\text { - search through company } \\
\text { employees, etc. }\end{array}$ & $\begin{array}{l}\text { Number of applicants for one } \\
\text { position: } \\
\text { - specialist engineer } \\
\text { - manager } \\
\text { - production }\end{array}$ & $\begin{array}{c}14 \\
67 \\
3\end{array}$ & $\begin{array}{c}19 \\
83 \\
5\end{array}$ \\
\hline \multirow{3}{*}{4} & \multirow{3}{*}{$\begin{array}{l}\text { Recruitment process } \\
\text { optimization: } \\
\text { - scorecard creation and } \\
\text { development of the } \\
\text { assessment program from } \\
\text { the first one; } \\
\text { - holding of a meeting } \\
\text { with management team to } \\
\text { obtain authority; } \\
\text { - request for back-up } \\
\text { assignment in case of } \\
\text { absence of the department } \\
\text { head; } \\
\text { - standardization of the } \\
\text { customer feedback } \\
\text { reception period; } \\
\text { - provision of the prompt } \\
\text { feedback to applicants; } \\
\text { - determination of the } \\
\text { medical checkup duration } \\
\text { (no more than } 14 \text { calendar } \\
\text { days); } \\
\text { - optimization according } \\
\text { to ECRS analysis }\end{array}$} & $\begin{array}{l}\text { The average time of selection } \\
\text { process in steps, taking into } \\
\text { account the anticipation (days): } \\
\text { Recruitment } \\
\text { - worker } \\
\text { - professional employee } \\
\text { Placement } \\
\text { - worker } \\
\text { - professional employee } \\
\text { Selection } \\
\text { Hiring }\end{array}$ & $\begin{array}{c}5 \\
14 \\
\\
1 \\
21 \\
5 \\
1\end{array}$ & $\begin{array}{c}0 \text { or } 3 \\
14 \\
1 \text { or } 0 \\
3 \\
1\end{array}$ \\
\hline & & $\begin{array}{l}\text { The average number of days } \\
\text { from job application receipt to } \\
\text { the first working day of a new } \\
\text { employee: } \\
\text { - worker } \\
\text { - professional employee }\end{array}$ & $\begin{array}{l}38 \\
68\end{array}$ & $\begin{array}{l}24 \\
47\end{array}$ \\
\hline & & Number of satisfied customers & 17 & 21 \\
\hline \multirow{3}{*}{ 5) } & \multirow{3}{*}{$\begin{array}{l}\text { Assistance in the new } \\
\text { employee orientation in } \\
\text { line with the performance } \\
\text { of the "staff voice" role }\end{array}$} & $\begin{array}{l}\text { Job vacancy filling quality = } \\
\text { number of employees } \\
\text { completed a probationary } \\
\text { period/number of hired*100\% }\end{array}$ & $89.88 \%$ & $98.95 \%$ \\
\hline & & $\begin{array}{lccc}\text { Job } & \text { vacancy } & \text { filling } & \text { plan } \\
\text { implementation } & & \\
\end{array}$ & $76 \%$ & $88 \%$ \\
\hline & & $\begin{array}{l}\text { Average staff turnover among } \\
\text { new employees, the number of } \\
\text { people: } \\
\text { for } 1 \text { month } \\
\text { for } 3 \text { months } \\
\text { for } 6 \text { months }\end{array}$ & $\begin{array}{l}3 \\
3 \\
1\end{array}$ & $\begin{array}{l}2 \\
1 \\
1\end{array}$ \\
\hline
\end{tabular}

\section{Results}

According to the data represented in the table, it is fair to say that the indicators are changing for the better, which makes it possible to consider the right direction of recruitment system improvement.

Using the results of analysis, one can find several problems existing in the HR field. Such problems include the lack of understanding who is your employee, what qualities he has and how he can be valuable to the department and overall company apart from performing routine tasks. In order to solve the given problem, the author and employees of Nestle Kuban Company's HR department carried out the data collation work concerning 
hired employees and their compliance with the policy of Nestle as a whole. After investigation of the current situation and key requirements of the department heads, the common values were identified on the basis of which the competency matrix was developed (table 2).

Table 2. The competency matrix of Nestle Kuban food factory.

\begin{tabular}{|c|c|c|c|c|}
\hline & & \multicolumn{3}{|c|}{ Applicant/employee level } \\
\hline \multirow{7}{*}{ ن } & & All employees & Leaders & Top leaders \\
\hline & $\begin{array}{l}\text { Know and beat } \\
\text { competitors }\end{array}$ & $\begin{array}{c}\text { Business terrain } \\
\text { insight }\end{array}$ & Vision & $\begin{array}{c}\text { Competitive ability } \\
\text { development }\end{array}$ \\
\hline & $\begin{array}{c}\text { Lead to } \\
\text { breakthrough }\end{array}$ & $\begin{array}{c}\text { Follow the } \\
\text { principles you } \\
\text { preach }\end{array}$ & $\begin{array}{c}\text { Motivation and } \\
\text { involvement }\end{array}$ & Ability to inspire \\
\hline & Achieve results & Setting for result & $\begin{array}{c}\text { Team achievement } \\
\text { of results }\end{array}$ & $\begin{array}{l}\text { Strategy development } \\
\text { and implementation }\end{array}$ \\
\hline & $\begin{array}{l}\text { Develop talents } \\
\text { and team }\end{array}$ & $\begin{array}{c}\text { Ability to assess } \\
\text { your skills }\end{array}$ & $\begin{array}{c}\text { Coaching and } \\
\text { development }\end{array}$ & $\begin{array}{c}\text { Company's capacity } \\
\text { development }\end{array}$ \\
\hline & $\begin{array}{l}\text { Cooperate intra- } \\
\text { company }\end{array}$ & $\begin{array}{l}\text { Active approach } \\
\text { to collaboration }\end{array}$ & $\begin{array}{l}\text { Ability to influence } \\
\text { and persuade }\end{array}$ & $\begin{array}{l}\text { Engagement culture } \\
\text { build-out }\end{array}$ \\
\hline & $\begin{array}{l}\text { Be eager for } \\
\text { changes }\end{array}$ & Creativity & Courage & $\begin{array}{c}\text { Deployment and } \\
\text { management of change }\end{array}$ \\
\hline
\end{tabular}

The given competency matrix can be used to further motivate employees and increase their engagement. The key KPIs of the department can be divided into personal goals and with the help of the matrix the employee can get the opportunity to understand what qualities he still needs to develop in order to achieve a certain strategic department goal. Upon reaching the end of the year and summing-up the department head will determine whether one or another skill was built, whether the employee possessed the needed competence, to what extent he was involved in the process, and what is his contribution to goal achievement. In accordance with the received involvement percent the employee will get a bonus.

This matrix is the basis for career advancement, enabling each employee to understand how to become a leader, and also providing additional motivation in the form of increase in the percentage of personal contribution to goal achievement. Application of such matrix demonstrates the strategic orientation of HR partnership and the development in the field of employee representative, as it has sufficient process transparence, but leaves some subjectivity of the assessment. The results can be systematized after a year after implementation.

\section{Discussion of the results}

It should be pointed out that within the entire process of staff recruitment improvement the recruiter performed new roles (strategist, admin expert, staff voice and change agent). It was the use of the Lean system methodology that made it possible for the recruiter to prove himself not only as the performer of the process, but also as an active groundbreaker, who knows and appreciates his contribution to the company's development.

The modified recruitment system encourages the switch to a new level of HR value in the enterprise's business. The developed modification technique based on the HRBP concept can further be used for the systems of other departments. 


\section{Conclusions}

Thus, considering the application of developed methodology based on the Lean system together with the suggested optimization measures, it can be said that these solutions made a good showing and encouraged the improvement of key staff recruitment indicators [1316].

This methodology enables to solve significant problems identified in the process of the analysis:

- the lack of understanding of the job seeker / company's employee ideal profile;

- the excessively long staff recruitment process with some stages replay in several sequences.

The solution of these problems enabled the food industry company Nestle Kuban LLC to standardize the staff recruitment process and its parts, reduce the subjectivity of applicants assessment, expand the search scope, increase the HR department involvement in the company's business, etc. Developed solutions in the context of systems approach to the personnel recruitment process and implementation of the Lean-based methodology can also be applied to other large food factories.

\section{References}

1. D. Standiford, N. Morwessel, F. Bishop and others, Contemporary Clinical Trials Communications 12, 68-75 (2018) doi.org/10.1016/j.conctc.2018.09.005

2. I. Pastor, Procedia Economics and Finance 3, 415-419 (2012) doi.org/10.1016/S22125671(12)00173-6

3. G. Ferris, H. Berkson, M. Harris, Human Resource Management Review 12(3), 359375 (2002)

4. S. Taylor, Human Resource Management Review 16(4), 478-489 (2006) doi.org/10.1016/j.hrmr.2006.08.005

5. H. Berkson, G. Ferris, M.M. Harris, Hum. Resour. Manage. Rev. 12, 359-375 (2002) doi.org/10.1016/S1053-4822(02)00095-5

6. C. Belinda, J. Westerman, S. Bergman, Journal of Vocational Behavior 109, 101-117 (2018) doi.org/10.1016/j.jvb.2018.10.001

7. G. Yadav, S. Luthra, D. Huisingh and others, Journal of Cleaner Production 245, 118726 (2020) doi.org/10.1016/j.jclepro.2019.118726

8. V. Ramakrishnan, J. Jayaprakash, C. Elanchezhian, B. Vijaya Ramnath, Materials Today: Proceedings 16(2), 1244-1250 (2019) doi.org/10.1016/j.matpr.2019.05.221

9. R. Henao, W. Sarache, I. Gómez, Journal of Cleaner Production 208, 99-116 (2019) doi.org/10.1016/j.jclepro.2018.10.116

10. J. Mbogo Kafuku, Procedia Manufacturing 33, 351-358 (2019) doi.org/10.1016/j.promfg.2019.04.043

11. A. Kurt Möldner, J. Arturo Garza-Reyes, V. Kumar, Journal of Business Research 106, 233-249 (2020) doi.org/10.1016/j.jbusres.2018.09.002

12. G. Marodin, A. Germán Frank, G. Luz Tortorella, T. Netland, International Journal of Production Economics 203, 301-310 (2018) doi.org/10.1016/j.ijpe.2018.07.009

13. K.A. Barmuta, A.A. Borisova, and M.P. Glyzina, Mediterranean Journal of Social Sciences 6(3S4), 91-96 (2015) doi: 10.5901/mjss.2015.v6n3s4p91

14. V.V. Mazur, K.A., Barmuta, S.S. Demin, E.A. Tikhomirov, M.A. Bykovskiy, International Journal of Economics and Financial Issues 6 (1S), 270-274 (2016) 
15. K. Barmuta, V. Ponkratov, M. Maramygin and others, Entrepreneurship and Sustainability Issues 7(1), 484-497 (2019) doi: 10.9770/jesi.7.1(34)

16. N.S. Plaskova, N.A. Prodanova, A.S. Samusenko, E.A. Erzinkyan, K.A. Barmuta, R.A. International Journal of Engineering and Advanced Technology 9(1), 2913-2916 (2019) doi:10.35940/ijeat.A1213.109119 